\title{
Plotting the equilibrium cerium content in metal under the slag of the $\mathrm{CaO}-\mathrm{SiO}_{2}-\mathrm{Ce}_{2} \mathrm{O}_{3}-15 \% \mathrm{Al}_{2} \mathrm{O}_{3}-8 \% \mathrm{MgO}$ system
}

\author{
(C) Anatoly A. Babenco, ${ }^{*}$ Leonid A. Smirnov, \\ Alena G. Upolovnikova, ${ }^{+}$and Lyudmila Yu. Mikhailova \\ Laboratory of Pyrometallurgy of Non-Ferrous Metals. FSBIS Institute of Metallurgy of the UB of the RAS. \\ Amundsen St., 101. Yekaterinburg, 620016. Sverdlovsk Region. Russia. \\ Phone:+7 (343) 232-91-62.E-mail:upol.ru@mail.ru
}

\begin{abstract}
*Supervising author; ${ }^{+}$Corresponding author
Keywords: cerium, metal, slag, experimental design, thermodynamic modeling, composition-property diagrams.
\end{abstract}

Abstract
Using the HSC 6.1 Chemistry (Outokumpu) software package in combination with simplex-lattice planning, we performed thermodynamic modeling of the equilibrium cerium content in a metal containing $0.06 \% \mathrm{C}, 0.25 \mathrm{Si}, 0.05 \% \mathrm{Al}$ (in this expression and further on the text indicates mass\%), under the slag of the $\mathrm{CaO}-\mathrm{SiO}_{2}-\mathrm{Ce}_{2} \mathrm{O}_{3}-15 \% \mathrm{Al}_{2} \mathrm{O}_{3}-8 \% \mathrm{MgO}$ system in a wide range of chemical composition at temperatures of $1550{ }^{\circ} \mathrm{C}$ and $1650^{\circ} \mathrm{C}$. For each temperature, adequate mathematical models have been obtained in the form of a reduced polynomial of degree III, describing the equilibrium content of cerium in the metal depending on the composition of the slag. The results of mathematical modeling are presented graphically in the form of diagrams of the composition - the equilibrium content of cerium. A marked effect of slag basicity on the distribution of cerium is noted. An increase in slag basicity from 2 to 5 at a temperature of $1550{ }^{\circ} \mathrm{C}$ leads to an increase in the equilibrium cerium content in the metal from 0.1 to $7 \mathrm{ppm}$, i.e. the increase in slag basicity favorably affects the development of cerium recovery process. An increase in metal temperature has a positive effect on cerium recovery. As the temperature rises to $1650{ }^{\circ} \mathrm{C}$, the equilibrium cerium content in the metal increases on average from 0.3 to $10 \mathrm{ppm}$. In the diagrams of the chemical composition of slags containing 56$61 \% \mathrm{CaO}, 12-14 \% \mathrm{SiO}_{2}$ and $15 \% \mathrm{Al}_{2} \mathrm{O}_{3}$ in the temperature range of 1550 and $1650{ }^{\circ} \mathrm{C}$, we can expect a concentration of cerium in the metal at a level of $7-10 \mathrm{ppm}$ at a content of $4 \%$ to $7 \% \mathrm{Ce}_{2} \mathrm{O}_{3}$ in the original slag. The positive effect of the basicity of the formed slag in the studied range of chemical composition on the cerium reduction process is explained from the standpoint of the phase composition of the slag and the thermodynamics of cerium reduction reactions.

\section{References}

[1] V.A. Golubtsov, V.V. Lunev. Steel modification for castings and ingots. Chelyabinsk-Zaporozhye: ZNTU. 2008. 356p. (russian)

[2] V.L. Pilyushenko, V.A. Vihlevschuk. Scientific and technological bases of microalloying steel. Moscow: Metallurgy. 2000. 384p. (russian)

[3] Y.G. Goldstein, L.B. Efimova. Modification and microalloying of iron and steel. Moscow: Metallurgy. 1986. 271p. (russian)

[4] G.N. Elansky. Steel and the periodic system of elements Mendeleev: a textbook for universities in the field of "Metallurgy". Moscow: MGVMI. 2012.196p. (russian)

[5] L.A. Smirnov, V.A. Rovnushkin, A.S. Oryshchenko, G.Yu. Kalinin, V.G. Milyuts. Modification of steel and alloys with rare earth elements. Message 1. Metallurgist. 2015. No.11. P.57-63. (russian)

[6] L.A. Smirnov, V.A. Rovnushkin, A.S. Oryshchenko, G.Yu. Kalinin, V.G. Milyuts. Modification of steel and alloys with rare earth elements. Message 2. Metallurgist. 2016. No.1. P.41-48. (russian)

[7] D.Yu. Petryna, O.L. Kozak, B.R. Shulyar, Yu.D. Petryna, M.I. Hredil. Influence of alloying by rare-earth metals on the mechanical properties of $17 \mathrm{G} 1 \mathrm{~S}$ pipe steel. Materials Science. 2013. Vol.48. No.5. P.575-581.

[8] V.D. Makarchenko, M.V. Kindrachuk. The effect of cerium on the mechanical and corrosive properties of low alloy pipe steels. Compression and power engineering. 2014. No.3. P.24-29. (russian)

[9] H. Torkamani, Sh. Raygan, C. Garcia-Mateo, J. Rassizadehghani, Y. Palizdar, D. San-Martin. Evolution of pearlite microstructure in low-carbon cast microalloyed steel due to the addition of $\mathrm{La}$ and $\mathrm{Ce}$. Metallurgical and materials transactions A. 2018. Vol.49A. P.4495-4508. 
[10] Y. Xiaohong, L. Hu, C. Guoguang, W. Chengchuan, W. Bin. Effect of refining slag containing Ce2O3 on steel cleanliness. Journal of rare earths. 2011. Vol.29. No.11. P.1079-1083.

[11] C. $\mathrm{Wu}, \mathrm{G}$. Cheng, H. Long and X. Yang. A thermodynamic model for evaluation of mass action concentrations of $\mathrm{Ce} 2 \mathrm{O} 3$-contained slag systems based on the ion and molecule coexistence theory high temp. Mater. Proc. 2013. Vol.32. No.3. P.207-214.

[12] H. Long. Measurements of physical properties of Ce contained refining slags and their effects on steel cleanliness. Master thesis of University of Science and Technology Beijing. 2011. Vol.32. P.169.

[13] M.X. Guo, H. Suito. Effect of dissolved cerium on austenite grain growth in Fe- 0.20 mass\%C$0.02 \mathrm{mas} \% \mathrm{P}$ alloy. ISIJ International. 1999. Vol.39. No.11. P.1169.

[14] S. Ueda, K. Morita, N. Sano. Activity of AlO1.5 for the CeO1.5-CaO-AlO1.5 system at 1773 K. ISIJ International. 1998. Vol.38. No.12. P.1292-1296.

[15] C. Wu, G. Cheng and $\mathrm{H}$. Long. Effect of $\mathrm{Ce}_{2} \mathrm{O}_{3}$ and $\mathrm{CaO} / \mathrm{Al}_{2} \mathrm{O}_{3}$ on the Phase, Melting Temperature and Viscosity of $\mathrm{CaO}-\mathrm{Al}_{2} \mathrm{O}_{3}-10$ Mass\% $\mathrm{SiO}_{2}$ Based Slags. High Temp. Mater. Proc. 2014. Vol.33. No.1. P.77-84.

[16] H. Feifei, L. Bo, L. Da, L. Ligang, D. Ting, R. Xuejun, Y. Qingxiang. Effects of rare earth oxide on hardfacing metal microstructure of medium carbon steel and its refinement mechanism. Journal of rare earths. 2011. Vol.29. No.6. P.609-613.

[17] A.A. Babenco, L.A. Smirnov, A.G. Upolovnikova, and O.V. Nechvoglod. Thermodynamic modeling of cerium reduction from slags of the $\mathrm{CaO}-\mathrm{SiO}_{2}-\mathrm{Ce}_{2} \mathrm{O}_{3}-15 \% \mathrm{Al}_{2} \mathrm{O}_{3}-8 \% \mathrm{MgO}$ system by dissolved aluminum in the metal. Butlerov Communications. 2019. Vol.59. No.9. P.140-145. DOI: 10.37952/ROI-jbc-01/19-59-9-140

[18] V.A. Kim, E.I. Nikolai, A.A. Akberdin, I.S. Kulikov. The planning experiment the study of physical chemical properties of metallurgical slags: Toolkit. Alma-Ata: Nauka. 1989. 116p.

[19] V.A. Kim, A.A. Akberdin, I.S. Kulikov. The use of lattices simplex charting-type structure - the viscosity. Izvestiya VUZov. Chernaya Metallurgiya. 1980. No.9. P.167-168. (russian)

[20] A.A. Babenko, V.I. Zhuchkov, L.I. Leontyev, A.G. Upolnikova. The equilibrium distribution of boron between the metal of the Fe-C-Si-Al system and boron-containing slag. News of higher educational institutions. Ferrous metallurgy. 2017. Vol.60. No.9. P.752-758. (russian) 